\title{
Phosphate and Nitrate Release from Mucky Mineral Soils
}

\author{
Michaël A. Leblanc ${ }^{1,2}$, Léon E. Parent ${ }^{1 *}$, Gilles Gagné ${ }^{2}$ \\ ${ }^{1}$ Department of Soils and Agri-Food Engineering, Université Laval, Québec, Canada; ${ }^{2}$ Research and Development Institute for the \\ Agri-Environment (IRDA), Québec, Canada. \\ Email: "leon-etienne.parent@fsaa.ulaval.ca
}

Received January $31^{\text {st }}, 2013$; revised February $13^{\text {th }}, 2013$; accepted February $22^{\text {nd }}, 2013$

Copyright (C) 2013 Michaël A. Leblanc et al. This is an open access article distributed under the Creative Commons Attribution License, which permits unrestricted use, distribution, and reproduction in any medium, provided the original work is properly cited.

\begin{abstract}
High-organic (mucky) mineral soils make a small proportion of the Canadian agricultural land but are highly productive, especially for organic farming. Although these high-quality soils may release large amounts of nitrate and phosphate to the environment, there is yet no reliable agro-environmental indicator for managing $\mathrm{N}$ and $\mathrm{P}$ compared to the adjacent mineral and organic soils. Our objective was to quantify the $\mathrm{N}$ mineralization and $\mathrm{P}$ environmental risks of mucky mineral soils. Nine Canadian soil series (eight Orthic Humic Gleysols and one Terric Humisol with three variants) were analyzed for texture, $\mathrm{pH}\left(\mathrm{CaCl}_{2}\right)$, total $\mathrm{C}$ and $\mathrm{N}$, oxalate and Mehlich-III (M-III) extractable $\mathrm{P}, \mathrm{Al}$ and $\mathrm{Fe}$, and water extractable $\mathrm{P}\left(\mathrm{P}_{\mathrm{w}}\right)$. Soil texture varied from loamy sand to heavy clay, organic carbon $(\mathrm{OC})$ content ranged from 14 to 392 $\mathrm{g} \cdot \mathrm{OC} \cdot \mathrm{kg}^{-1}$, total $\mathrm{N}$ from 1.21 to $16.38 \mathrm{~g} \cdot \mathrm{N} \cdot \mathrm{kg}^{-1}$, and degree of $\mathrm{P}$ saturation $\left(\mathrm{DPS}_{\mathrm{M}-\mathrm{III}}\right)$ as molar $(\mathrm{P} /[\mathrm{Al}+\gamma \mathrm{Fe}])_{\mathrm{M}-\mathrm{III}}$ percentage between $0.3 \%$ and $11.3 \%$. After $100 \mathrm{~d}$ of incubation, soils released 31 to $340 \mathrm{mg} \cdot \mathrm{N} \cdot \mathrm{kg}^{-1}$. The $\mathrm{N}$ mineralization rate was closely correlated to organic matter content $(\mathrm{r}=0.91, \mathrm{p}<0.01)$. Sandy to loamy soils released $1.2-1.8$ $\mathrm{kg} \cdot \mathrm{N} \cdot \mathrm{ha}^{-1} \cdot \mathrm{d}^{-1}$ compared to $1.6-2.4 \mathrm{~kg} \cdot \mathrm{N} \cdot \mathrm{ha}^{-1} \cdot \mathrm{d}^{-1}$ for clayey soils, $2.0-2.8 \mathrm{~kg} \cdot \mathrm{N} \cdot \mathrm{ha}^{-1} \cdot \mathrm{d}^{-1}$ for mucky clayey soils and $2.6-2.7 \mathrm{~kg} \cdot \mathrm{N} \cdot \mathrm{ha}^{-1} \cdot \mathrm{d}^{-1}$ for Humisol. For $(\mathrm{P} /[\mathrm{Al}+3 \mathrm{Fe}])_{\mathrm{M}-\mathrm{III}}$ ratios of mucky clayey soils below $4.5 \%$, water-extractable $\mathrm{P}$ did not exceed threshold of $9.7 \mathrm{mg} \mathrm{P}_{\mathrm{w}} \mathrm{L}^{-1}$. Mucky clayey soils could be managed for $\mathrm{N}$ similarly to Humisol and for $\mathrm{P}$ with $(\mathrm{P} /[\mathrm{Al}+3 \mathrm{Fe}])_{\mathrm{M}-\text { III }}$ percentage not exceeding $4.5 \%$.
\end{abstract}

Keywords: Degree of Phosphate Saturation; Gleysol; Humisol; Organic Nitrogen Mineralization; Zero-Order Kinetics

\section{Introduction}

Mucky soils occupy a small portion of the agricultural area in the St-Lawrence Lowlands, Québec, Canada, but have suitable physical, chemical, and biological soil quality attributes for vegetable cropping especially under organic farming. In Canada, the distinction between mineral soils and organic soils is based on the organic carbon content, mineral soils showing $17 \%$ OC or less by weight [1]. Mineral soils containing more than $9 \%$ OC by weight are classified as mucky soils [2] and soils high in organic carbon ( $4 \%-9 \%$ OC) [3] as weakly mucky.

Soil quality is defined as soil's capacity to function within ecosystem to sustain biological productivity, maintain environmental quality and promote plant and animal health [4,5]. Total $\mathrm{C}$ and $\mathrm{N}$ as well as plant-available mineral $\mathrm{N}$ and phosphate are chemical indicators of soil quality. Mucky mineral soils may release large amounts of nitrate and phosphate to the environment but there are no well documented indicators for safely managing $\mathrm{N}$

${ }^{*}$ Corresponding author. and $\mathrm{P}$.

In average, the arable layer of prairie mineral soils contain $0.65-3.21 \mathrm{~g}$ total $\mathrm{N} \cdot \mathrm{kg}^{-1}$ [6] compared to 3.3 to $24.5 \mathrm{~g}$ total $\mathrm{N} \cdot \mathrm{kg}^{-1}$ for organic soils [7]; $93 \%-97 \%$ of this $\mathrm{N}$ is in organic form [8]. In general, $1 \%-3 \%$ of total organic $\mathrm{N}$ is converted to mineral $\mathrm{N}$ during the growing season [8]. Hence, potentially mineralizable $\mathrm{N}$ appears to be considerable in mucky mineral soils.

On the other hand, soil P release depends largely on the amount of $\mathrm{Al}$ and $\mathrm{Fe}$ oxy-hydroxides in both mineral [9] and organic [10] soils. The degree of phosphate saturation based on the oxalate method (DPS ${ }_{\text {ox }}$ ) has been proposed to assess $\mathrm{P}$ environmental risk [11]. The $\mathrm{DPS}_{\mathrm{ox}}$ is the ratio between oxalate-extractable $\mathrm{P}$ and $\mathrm{P}$ sorption capacity represented by oxalate-extracted $\mathrm{Al}$ and $\mathrm{Fe}$ oxy-hydroxides corrected by a factor for maximum sorption. The DPS ${ }_{\text {ox }}$ should not be allowed to exceed $25 \%$ to avoid polluting groundwater or waters discharged by subsurface drainage. For acid coarse-textured soils of Québec, this critical value corresponded to water-soluble $\mathrm{P}$ of $9.7 \mathrm{mg} \mathrm{P}_{\mathrm{w}} \mathrm{L}^{-1}$ [12]. It is noteworthy that this critical 
DPS $_{\text {ox }}$ value cannot be applied to pollution by runoff waters because it is assumed that all extra water is evacuated through the subsurface water system where total $\mathrm{P}$ concentration must not exceed $0.03 \mathrm{mg} \cdot \mathrm{P} \cdot \mathrm{L}^{-1}[9]$.

Because the oxalate method is not a routine method in North American laboratories, [12] proposed using $(\mathrm{P} / \mathrm{Al})_{\mathrm{M}-\mathrm{III}}$ or $(\mathrm{P} /[\mathrm{Al}+\mathrm{Fe}])_{\mathrm{M}-\text { III }}$ percentages as $\mathrm{DPS}_{\mathrm{M}-\mathrm{III}}$. In general, the Mehlich-III extracted Fe did not add significant information when relating $\mathrm{DPS}_{\mathrm{M} \text {-III }}$ to $\mathrm{DPS}_{\mathrm{ox}}$. Nevertheless, [13] argued that $\mathrm{Al}$ and $\mathrm{Fe}$ should be amalgammated to reflect soil's capacity to sorb $\mathrm{P}$. The $(\mathrm{P} / \mathrm{Al})_{\mathrm{M}-\mathrm{III}}$ $\left(\mathrm{mg} \cdot \mathrm{kg}^{-1}\right)$ ratio equaled $1.39 \times(\mathrm{P} /[\mathrm{Al}+\mathrm{Fe}])_{\mathrm{M}-\mathrm{III}}$ $\left(\mathrm{mmol} \cdot \mathrm{kg}^{-1}\right)$ with $\mathrm{r}^{2}=0.99$ in Quebec soils [9]. The $(\mathrm{P} / \mathrm{Al})_{\mathrm{M}-I I I}$ ratio was found to be superior to $\mathrm{P}_{\mathrm{M} \text {-III }}$ alone to classify soil $\mathrm{P}$ fertility according to probability of crop response to added $\mathrm{P}$ [14], indicating that the plant must compete with soil sorbents for available phosphate. Because the Mehlich-III method ineffectively extracted $\mathrm{Fe}$ in organic soils it was proposed inflating extracted $\mathrm{Fe}$ by a factor of 5, i.e., $\mathrm{DPS}_{\mathrm{M}-\mathrm{III}}=100(\mathrm{P} /[\mathrm{Al}+\gamma \mathrm{Fe}])_{\mathrm{M}-\mathrm{III}}$ where $\gamma=5$ [10]. The value for $\gamma$ could be adapted for managing $\mathrm{P}$ in mucky mineral soils.

Our objectives were 1) to determine potentially mineralizable organic $\mathrm{N}$ in mineral, mucky mineral and organic soils; and 2) to propose a critical $\mathrm{DPS}_{\mathrm{M} \text {-III }}$ for mucky mineral soils that prevents environmental $\mathrm{P}$ pollution of groundwater.

\section{Material and Methods}

\subsection{Soil Classification}

The arable layers of soils in the flat landscape of the St-Lawrence River are made of marine deposits of the Champlain Sea as well as estuarine, glacial and fluvial deposits from the Post-Champlain era. The climate is temperate continental with annual precipitation of 1000 $\mathrm{mm}(30 \%-40 \%$ in the summer season). The frost-free season (90\% probability) is 169 days; there are 1939 2125 degree-days exceeding $5^{\circ} \mathrm{C}$, indicating favorable conditions for cropping.

We investigated nine soil series $[3,15]$ as follows: Aston (AS) loamy sand, Des Chenaux (CH) loam, Du Jour (DJ) clay loam, Laplaine (LP) clay, Massueville (MS) sandy loam, Providence (PV) heavy clay, Sainte-Rosalie (RO) clay, Saint-Urbain (UB) heavy clay, and Verchères (VE) organic soil, located on the IRDA research organic farm at St-Bruno-de-Montarville near Montréal, Québec, Canada ( $\left.45^{\circ} 33^{\prime} 13^{\prime \prime} \mathrm{N}, 73^{\circ} 20^{\prime} 58^{\prime \prime} \mathrm{W}\right)$.

Along a gradient from mineral to organic materials, the texture of mineral and mucky mineral soils varied from sandy to clayey material. A gradient of soil series in the same catena can avoid comparing soils with wide differences in mineralogy and genesis. Soils were classified as Orthic Humic Gleysol (AS, CH, DJ, LP, MS, PV,
RO, and UB) or Terric Humisol (VE).

For the $\mathrm{N}$ incubation study, we collected eleven surface soil (Ap or Op horizon) samples from the eight mineral soil series and the three variants of the organic soil series. For the P study, we collected 80 surface soil samples varying in physical and chemical properties.

\subsection{Soil Analysis}

The $\mathrm{pH}$ was measured in $0.01 \mathrm{M} \mathrm{CaCl}_{2}(1: 2$ for mineral soils and 1:4 for organic soils). The $\mathrm{P}, \mathrm{Al}$ and Fe were extracted using the Mehlich III [16] and the acid oxalate methods [17] for comparison with other studies on mineral and organic soils. The Mehlich-III extracting solution is made of $0.2 M \mathrm{CH}_{3} \mathrm{COOH}, 0.25 \mathrm{M} \mathrm{NH}_{4} \mathrm{NO}_{3}$, $0.015 M \mathrm{NH}_{4} \mathrm{~F}, 0.013 M \mathrm{HNO}_{3}$, and $0.001 M$ EDTA. The oxalate extraction solution comprises $0.2 \mathrm{M}\left(\mathrm{NH}_{4}\right)_{2} \mathrm{C}_{2} \mathrm{O}_{4}$ and $0.2 \mathrm{M} \mathrm{H}_{2} \mathrm{C}_{2} \mathrm{O}_{4}$, adjusted at $\mathrm{pH} 3$. Water soluble $\mathrm{P}$ was extracted according to [18]. Soil extracts were quantified by ICP-OES (Inductively Coupled Plasma-Optical Emission Spectroscopy). Total $\mathrm{C}$ and $\mathrm{N}$ were determined using the LECO CR-412 analyzer and by micro-Kjeldahl [19], respectively.

Bulk density was determined using the cylinder method [20]. Soil texture was determined by sedimentation after destroying organic matter with peroxide $\left(\mathrm{H}_{2} \mathrm{O}_{2}\right.$, $30 \%$ ) for soils containing more than $5 \%$ organic matter [21].

\subsection{Soil Incubation}

An amount of $75 \mathrm{~g}$ of fresh 8-mm sieved soils was incubated in duplicate at $30^{\circ} \mathrm{C}$ and $80 \%$ relative air humidity in $400-\mathrm{mL}$ jars. Soil moisture was maintained at approximately $60 \%$ of field capacity with deionized water. Soils were extracted with $2 \mathrm{~N} \mathrm{KCl} \mathrm{[22]} \mathrm{after} \mathrm{0,} \mathrm{10,} \mathrm{20,} \mathrm{30,}$ $40,60,80$, and $100 \mathrm{~d}$ of incubation and analyzed for $\mathrm{NH}_{4}-\mathrm{N}$ and $\mathrm{NO}_{3}-\mathrm{N}$ with Technicon Autoanalyser. Net mineralization of organic $\mathrm{N}$ was modeled by zero-order kinetics as follows:

$$
N_{t}=k t+N_{i}
$$

where $k$ is mineralization rate $\left(\mathrm{mg} \cdot \mathrm{kg}^{-1} \cdot \mathrm{d}^{-1}\right), N_{i}$ is mineral $\mathrm{N}$ extracted at time zero $\left(\mathrm{mg} \cdot \mathrm{N} \cdot \mathrm{kg}^{-1}\right)$, and $N_{t}$ is mineral $\mathrm{N}$ extracted $\left(\mathrm{mg} \cdot \mathrm{N} \cdot \mathrm{kg}^{-1}\right)$ at time $t>0$ (d). Mineralized $\mathrm{N}$ was measured as $N_{t}-N_{i}$.

\subsection{Soil P Saturation}

The DPS $_{\text {ox }}$ was computed as follows [11]:

$$
\operatorname{DPS}_{\mathrm{ox}}(\%)=100 \frac{\mathrm{P}_{\mathrm{ox}}}{\propto_{m}\left(\mathrm{Al}_{\mathrm{ox}}+\mathrm{Fe}_{\mathrm{ox}}\right)}
$$

where $\mathrm{P}_{\mathrm{ox}}, \mathrm{Al}_{\mathrm{ox}}$ and $\mathrm{Fe}_{\mathrm{ox}}$, expressed in $\mathrm{mmol} \cdot \mathrm{kg}^{-1}$, are extracted by the acid ammonium oxalate method [17] and is maximum saturation factor for total sorption $\left(\alpha_{\mathrm{m}}=\right.$ 
0.5 for mineral soils and 0.4 for organic soils). The $\alpha_{\mathrm{m}}$ factor was less for organic soils to account for competetion of organic ligands for sorption sites [23]. References $[10,12]$ suggested the following equation for $D P S_{M-I I I}$ :

$$
\mathrm{DPS}_{\mathrm{M}-\mathrm{III}}=100 \frac{\mathrm{P}_{\mathrm{M}-\mathrm{III}}}{\mathrm{Al}_{\mathrm{M}-\mathrm{III}}+\gamma \mathrm{Fe}_{\mathrm{M}-\mathrm{III}}}
$$

where $\mathrm{P}_{\mathrm{M}-\mathrm{III}}, \mathrm{Al}_{\mathrm{M} \text {-III }}$ and $\mathrm{Fe}_{\mathrm{M}-\mathrm{III}}$, expressed in $\mathrm{mmol} \cdot \mathrm{kg}^{-1}$, are extracted by the Mehlich III method [16] and $\gamma=0$ or 1 for mineral soils $[12,13]$ and $\gamma=5$ for organic soils [10].

\subsection{Statistical Analysis}

The zero-order $\mathrm{N}$ mineralization model was evaluated using linear regression [24]. Factor $\gamma$ was obtained by relating $\mathrm{DPS}_{\mathrm{M} \text {-III }}$ to $\mathrm{P}_{\mathrm{w}}$ and optimizing the relationship using the Cate-Nelson partitioning procedure where a maximum number of points are allotted to true negative and true positive quadrants [25].

When proportions are analyzed statistically, the results are biased by data redundancy, scale dependency and inherent non-normal distribution [26]. One proportion is always redundant because it is computed by difference between $100 \%$ (or the scale of measurement) and other proportions or concentrations. Scale dependency is due to the fact that when expressing the proportions on different scales of measurement (e.g., dry or wet mass basis), the interpretation of the results of the statistical analysis will differ. Inherent non-normal distribution refers to the closed compositional space constrained between zero and the unit of measurement rather than ranging across the real space $( \pm \infty)$ as is the case for a normal distribution. The log ratios avoid these problems and are most appropriate for the multivariate analysis of compositional data without bias [27-29].

The isometric log-ratios (ilr) project compositional data into a Euclidean space of D-1 non-overlapping orthogonal log-contrasts, also called orthonormal balances or "coordinates" [28]. A system of balances is formalized by a sequential binary partition $(\mathrm{SBP})$, a (D-1) $\times \mathrm{D}$ matrix, in which parts labeled " +1 " (group numerator) are contrasted with parts labeled " -1 " (group denominator) in each ordered row until the $(+1)$ and $(-1)$ subsets each contain a single part. For the $i$ th row of the SBP matrix, the balances are computed as follows:

$$
i l r_{i}=\sqrt{\frac{r_{i} s_{i}}{r_{i}+s_{i}}} \ln \frac{g\left(c_{i}^{+}\right)}{g\left(c_{i}^{-}\right)}
$$

where $r$ is the number of components in the $(+)$ group, $s$ is the number of components in the minus $(-)$ group, $g\left(c_{i}^{+}\right)$is the geometric mean of components at numerator $(+)$ group and $g\left(c_{i}^{-}\right)$is the geometric mean of components at denominator $(-)$ group. Each contrast multiplied by an orthogonal coefficient is a coordinate in the Euclidian space. In the case of $\mathrm{N}$ mineralization, the two balances include a $\log$ contrast between $\mathrm{C}$ and $\mathrm{N}$ (the classical $\mathrm{C} / \mathrm{N}$ ratio) and a contrast between the $\mathrm{C}$ and $\mathrm{N}$ pools and $\mathrm{Fv}$, the filling value between $100 \%$ and proportions of $\mathrm{C}$ and $\mathrm{N}$.

The balance concept provides the Euclidean geometry required to compute a multivariate compositional distance called "Aitchison distance" $(\mathcal{A})$, between two equal-length compositions $x$ and $y$ (referential composition) [30] as follows:

$$
\mathcal{A}=\sqrt{d^{2}(x, y)}=\sqrt{\sum_{i=1}^{D-1}\left({ }^{x} i l r_{i}-{ }^{y} i l r_{i}\right)^{2}}
$$

Using the most favorable composition for $\mathrm{N}$ mineralization as referential composition, the greater the $\mathcal{A}$, the lesser is the rate of organic $\mathrm{N}$ mineralization in soils. The $\mathcal{A}$ thus provides a means to classify soils along a gradient of $\mathrm{N}$ mineralization potentials.

\section{Results and Discussion}

\subsection{Soil Properties}

Soil properties are presented in Table 1. Total N varied between 1.2 and $16.4 \mathrm{mg} \cdot \mathrm{kg}^{-1}$, within ranges reported by [6] for Canadian mineral soils and by [7] for Canadian organic soils. The $\mathrm{C} / \mathrm{N}$ ratios ranged between 10.8 and 23.9 , i.e., lower than the critical value of 30 for $\mathrm{N}$ mineralization [8]. Little correlation was found between $\mathrm{pH}$ and $\mathrm{N}$ mineralization in 20 Québec mineral soils in the $\mathrm{pH}\left(\mathrm{CaCl}_{2}\right)$ range of $5.3-7.3$ [31]. There is no nitrate production in organic soils at $\mathrm{pH}\left(\mathrm{CaCl}_{2}\right)$ values below 4.5 [32]. Therefore, $\mathrm{pH}$ did not appear to limit nitrification, except possibly for AS, where $\mathrm{pH}$ was close to 5.0.

In the $\mathrm{P}$ study, there were 36 mineral soil samples ( $\leq 4 \%$ OC), 30 mucky clayey soil samples $(4 \%<$ OC $\leq$ $17 \%$ ) and 14 organic soil samples $(>17 \%$ OC) varying in physical and chemical properties (Table 2). The P, Al and Fe extracted by the Mehlich-III and oxalate methods were within ranges reported by [9] for Canadian podzolic and gleysolic soils and by [10] for Canadian organic soils (Table 2).

\subsection{Mineralization of Organic $\mathbf{N}$}

The coefficients of variation of mineral $\mathrm{N}$ concentrations varied between 3 and $9 \%$. The zero-order kinetics models showed high $\mathrm{r}^{2}$ values (Table 3), indicating that such models reliably assessed $\mathrm{N}$ mineralization rates. The $\mathrm{N}$ mineralization rate was closely related to organic matter content $(r=0.91)$ as reported elsewhere [7,8,31]. In mineral soils, $\mathrm{N}$ mineralization rate varied between 0.32 and $0.54 \mathrm{mg} \mathrm{N} \cdot \mathrm{kg}^{-1} \cdot \mathrm{d}^{-1}$, within range between 0.24 and 0.60 $\mathrm{mg} \mathrm{N} \cdot \mathrm{kg}^{-1} \cdot \mathrm{d}^{-1}$ obtained by [33]. The $\mathrm{N}$ mineralization rate ranged between 1.06 and $1.58 \mathrm{mg} \mathrm{N} \cdot \mathrm{kg}^{-1} \cdot \mathrm{d}^{-1}$ in 
Table 1. Soils properties for the $\mathrm{N}$ incubation study.

\begin{tabular}{ccccccccccc}
\hline Soil $^{\S}$ & Ap & Sand & Silt & Clay & BD & SOM & SOC & SON & C/N & $\left.\mathrm{pH}_{(\mathrm{CaCl}}\right)$ \\
\hline MS & 26 & 81 & 4 & 15 & 1.44 & 24 & 14 & 1.21 & 11.6 & 5.36 \\
DJ & 22 & 39 & 23 & 38 & 1.38 & 28 & 16 & 1.32 & 12.1 & 5.11 \\
AS & 28 & 83 & 4 & 13 & 1.52 & 29 & 17 & 1.35 & 12.6 & 4.96 \\
UB & 27 & 0 & 29 & 71 & 1.40 & 29 & 17 & 1.54 & 11.0 & 6.73 \\
PV & 26 & 6 & 34 & 60 & 1.56 & 31 & 18 & 1.66 & 10.8 & 6.37 \\
RO & 33 & 8 & 33 & 59 & 1.42 & 38 & 22 & 1.86 & 11.8 & 6.26 \\
LP & 26 & 15 & 32 & 53 & 0.68 & 114 & 66 & 4.00 & 16.5 & 5.05 \\
VEp & 23 & 20 & 23 & 57 & 0.83 & 153 & 89 & 5.10 & 17.4 & 4.97 \\
CH $^{\dagger}$ & 22 & 42 & 36 & 22 & 0.98 & 315 & 183 & 10.48 & 17.5 & 5.97 \\
VEs $^{\dagger}$ & 23 & - & - & - & 0.72 & 371 & 215 & 10.61 & 20.3 & 5.59 \\
VEd $^{\dagger}$ & 23 & - & - & - & 0.34 & 676 & 392 & 16.38 & 23.9 & 5.60 \\
\hline
\end{tabular}

${ }^{\S}$ See text for full names of soil series; 'Phase and variant of the VE series: high SOM mineral layer (VEp), shallow organic variant (VEs), deep organic variant (VEd); Ap = thickness of the arable layer; $\mathrm{BD}=$ soil bulk density; $\mathrm{SOM}=$ soil organic matter; $\mathrm{SOC}=$ soil organic carbon; $\mathrm{SON}=$ soil organic nitrogen. Mineral, mucky mineral and organic soils separated by horizontal lines.

Table 2. Range of mineral, mucky mineral and organic soils properties for the $P$ saturation study.

\begin{tabular}{|c|c|c|c|c|c|c|c|c|c|c|c|}
\hline & Clay & SOC & $\mathrm{P}_{\mathrm{M}-\mathrm{III}}$ & $\mathrm{Al}_{\mathrm{M}-\mathrm{III}}$ & $\mathrm{Fe}_{\mathrm{M}-\mathrm{III}}$ & $\mathrm{DPS}_{\mathrm{M}-\mathrm{III}}$ & $\mathrm{P}_{\mathrm{ox}}$ & $\mathrm{Al}_{\mathrm{ox}}$ & $\mathrm{Fe}_{\mathrm{ox}}$ & $\mathrm{DPS}_{\mathrm{ox}}$ & $\mathrm{P}_{\mathrm{w}}$ \\
\hline & $\%$ & $\mathrm{~g} \cdot \mathrm{kg}^{-1}$ & & $\mathrm{mg} \cdot \mathrm{kg}^{-1}$ & & $\%$ & & $\mathrm{mg} \cdot \mathrm{kg}^{-1}$ & & $\%$ & $\mathrm{mg} \cdot \mathrm{L}^{-1}$ \\
\hline \multicolumn{12}{|c|}{ Mineral soils $\left(\mathrm{n}=36 ; \gamma=1 ; \alpha_{\mathrm{m}}=0.5\right)$} \\
\hline Min & 9 & 7 & 4 & 948 & 158 & 0.3 & 329 & 2267 & 2826 & 9.6 & 2.7 \\
\hline Max & 71 & 34 & 203 & 1485 & 397 & 11.3 & 1018 & 8179 & 10,188 & 28.4 & 17.3 \\
\hline Mean & 50 & 19 & 61 & 1111 & 271 & 4.2 & 623 & 3348 & 5229 & 18.7 & 8.2 \\
\hline SD & 17 & 7.2 & 39 & 120 & 61 & 2.3 & 162 & 1156 & 1557 & 4.5 & 4.1 \\
\hline \multicolumn{12}{|c|}{ Mucky mineral soils $\left(\mathrm{n}=30 ; \gamma=3 ; \alpha_{\mathrm{m}}=0.45\right)$} \\
\hline Min & 28 & 43 & 10 & 729 & 142 & 0.6 & 541 & 2434 & 4119 & 14.3 & 3.1 \\
\hline Max & 76 & 164 & 95 & 1531 & 367 & 5.4 & 1689 & 10,434 & 15,009 & 27.9 & 14.1 \\
\hline Mean & 59 & 88 & 53 & 1134 & 254 & 3.0 & 956 & 5497 & 6113 & 22.1 & 7.0 \\
\hline SD & 10 & 38 & 27 & 244 & 63 & 1.4 & 294 & 2159 & 1961 & 3.1 & 3.2 \\
\hline \multicolumn{12}{|c|}{ Organic soils $\left(\mathrm{n}=16 ; \gamma=5 ; \alpha_{\mathrm{m}}=0.4\right)$} \\
\hline Min & - & 180 & 10 & 593 & 201 & 1.0 & 132 & 2183 & 4320 & 5.6 & 1.8 \\
\hline Max & - & 484 & 41 & 1331 & 614 & 3.2 & 1393 & 12,245 & 9421 & 20.1 & 5.9 \\
\hline Mean & - & 275 & 19 & 879 & 336 & 1.6 & 660 & 6148 & 6989 & 14.3 & 3.4 \\
\hline SD & - & 88 & 9 & 189 & 119 & 0.6 & 337 & 2956 & 1183 & 4.4 & 0.9 \\
\hline $\operatorname{Min}^{\S}$ & 0 & 3 & 8 & 496 & 122 & 0.4 & 217 & 270 & 560 & 9.3 & 0 \\
\hline $\operatorname{Max}^{\S}$ & 95 & 80 & 640 & 2424 & 844 & 48 & 1457 & 37,638 & 19,992 & 88 & 93.3 \\
\hline $\operatorname{Min}^{\dagger}$ & - & 147 & 2 & 1 & 9 & 0.3 & 24 & 106 & 207 & 3.3 & 0 \\
\hline $\operatorname{Max}^{\dagger}$ & - & 580 & 531 & 817 & 586 & 42 & 2233 & 8642 & 9397 & 104 & 100.3 \\
\hline
\end{tabular}

${ }^{\S}$ Reference [9] for mineral soils; ${ }^{\dagger}$ Reference [10] for organic soils; SOC $=$ soil organic carbon, DPS = Degree of P saturation Mehlich III (M-III) and oxalate (ox), $\operatorname{Min}=$ minimum, $\operatorname{Max}=$ maximum, $\mathrm{SD}=$ standard deviation. 
Table 3. Mineralization of organic $\mathbf{N}$ during the 100-d incubation period simulated by a zero-order kinetics model.

\begin{tabular}{|c|c|c|c|c|c|c|c|c|c|c|c|c|c|c|c|}
\hline \multirow[t]{2}{*}{ Soil $^{\S}$} & \multirow[t]{2}{*}{ Rep } & \multicolumn{8}{|c|}{ Mineralized $\mathrm{N}\left(\mathrm{mg} \cdot \mathrm{N} \cdot \mathrm{kg}^{-1}\right)$ by period $(\mathrm{d})$} & \multicolumn{3}{|c|}{ Mineralized $\mathrm{N}$ after $100 \mathrm{~d}$} & \multicolumn{2}{|c|}{$\mathrm{k}$} & \multirow[t]{2}{*}{$r^{2}$} \\
\hline & & 0 & 10 & 20 & 30 & 40 & 60 & 80 & 100 & $\mathrm{mg} \cdot \mathrm{N} \cdot \mathrm{kg}^{-1}$ & $\%$ total $\mathrm{N}$ & $\mathrm{kg} \cdot \mathrm{N} \cdot \mathrm{ha}^{-1}$ & $\mathrm{mg} \cdot \mathrm{N} \cdot \mathrm{kg}^{-1} \cdot \mathrm{d}^{-1}$ & $\mathrm{~kg} \cdot \mathrm{N} \cdot \mathrm{ha}^{-1} \cdot \mathrm{d}^{-1}$ & \\
\hline MS & 1 & 23 & 24 & 31 & 34 & 30 & 41 & 46 & 54 & \multirow[b]{2}{*}{$31^{\dagger}$} & \multirow[b]{2}{*}{2.5} & \multirow[b]{2}{*}{114} & \multirow[b]{2}{*}{0.32} & \multirow[b]{2}{*}{1.21} & \multirow[b]{2}{*}{0.87} \\
\hline MS & 2 & 24 & 22 & 32 & 39 & 34 & 37 & 61 & 53 & & & & & & \\
\hline DJ & 1 & 5 & 10 & 15 & 24 & 23 & 27 & 36 & 52 & \multirow[b]{2}{*}{47} & \multirow[b]{2}{*}{3.6} & \multirow[b]{2}{*}{143} & \multirow[b]{2}{*}{0.43} & \multirow[b]{2}{*}{1.29} & \multirow[b]{2}{*}{0.96} \\
\hline DJ & 2 & 5 & 10 & 15 & 23 & 21 & 27 & 39 & 52 & & & & & & \\
\hline AS & 1 & 21 & 27 & 31 & 35 & 39 & 50 & 54 & 65 & \multirow{2}{*}{44} & \multirow{2}{*}{3.2} & \multirow{2}{*}{185} & \multirow{2}{*}{0.43} & \multirow{2}{*}{1.83} & \multirow{2}{*}{0.98} \\
\hline AS & 2 & 21 & 26 & 31 & 41 & 39 & 49 & 60 & 64 & & & & & & \\
\hline UB & 1 & 6 & 10 & 15 & 26 & 20 & 26 & 46 & 69 & \multirow[b]{2}{*}{58} & \multirow[b]{2}{*}{3.7} & \multirow{2}{*}{217} & \multirow[b]{2}{*}{0.54} & \multirow[b]{2}{*}{2.05} & \\
\hline UB & 2 & 6 & 11 & 15 & 22 & 20 & 28 & 51 & 57 & & & & & & 0.92 \\
\hline PV & 1 & 4 & 9 & 13 & 17 & 18 & 26 & 35 & 47 & 43 & & & & & \\
\hline PV & 2 & 4 & 8 & 13 & 19 & 17 & 22 & 31 & 44 & 40 & 2.5 & 168 & 0.38 & 1.55 & 0.97 \\
\hline $\mathrm{RO}$ & 1 & 6 & 10 & 18 & 24 & 21 & 35 & 37 & 62 & 56 & & & & 237 & 090 \\
\hline RO & 2 & 6 & 11 & 17 & 24 & 19 & 35 & 43 & 63 & 56 & 3.0 & 262 & 0.51 & 2.37 & 0.94 \\
\hline LP & 1 & 24 & 38 & 54 & 71 & 80 & 122 & 157 & 172 & 148 & & & & & \\
\hline LP & 2 & 25 & 37 & 52 & 75 & 85 & 117 & 147 & 187 & 162 & 3.9 & 274 & 1.58 & 2.80 & 0.99 \\
\hline VEp & 1 & 16 & 30 & 41 & 55 & 57 & 85 & 100 & 134 & 118 & & & & & \\
\hline VEp & 2 & 17 & 33 & 38 & 62 & 60 & 84 & 103 & 120 & 103 & 2.2 & 211 & 1.06 & 2.03 & 0.98 \\
\hline $\mathrm{CH}$ & 1 & 13 & 22 & 30 & 46 & 45 & 63 & 81 & 105 & 92 & & & & & \\
\hline $\mathrm{CH}$ & 2 & 14 & 26 & 31 & 46 & 45 & 68 & 84 & 92 & 78 & 0.8 & 183 & 0.84 & 1.80 & 0.98 \\
\hline VEs & 1 & 18 & 35 & 49 & 74 & 82 & 110 & 160 & 181 & 163 & & & & & \\
\hline VEs & 2 & 18 & 36 & 54 & 85 & 79 & 110 & 159 & 175 & 157 & 1.5 & 263 & 1.62 & 2.67 & 0.99 \\
\hline VEd & 1 & 38 & 71 & 84 & 136 & 167 & 231 & 290 & 408 & 370 & 1 & 266 & 240 & 767 & 006 \\
\hline VEd & 2 & 35 & 61 & 78 & 201 & 176 & 244 & 313 & 346 & 310 & & & & & \\
\hline
\end{tabular}

${ }^{\S}$ See text for full names of soil series, ${ }^{\dagger}$ Average of replicates 1 and 2. Rep $=$ replicate, $\mathrm{k}=\mathrm{N}$ mineralization rate. Mineral (top), mucky mineral (middle), and organic soils (bottom) separated by horizontal lines.

mucky clayey soils and between 0.84 and $3.40 \mathrm{mg}$ $\mathrm{N} \cdot \mathrm{kg}^{-1} \cdot \mathrm{d}^{-1}$ in organic soils, compared to the range between -0.16 and $1.91 \mathrm{mg} \mathrm{N} \cdot \mathrm{kg}^{-1} \cdot \mathrm{d}^{-1}$ measured in organic soils [7]. The potential for $\mathrm{N}$ mineralization was high in VEd because minerotrophic peat materials have considerable nitrate release capacity [32]. As shown in Figure 1, mucky clayey soils behave similarly to organic soil materials. Mineral soils showed lower N mineralization rates.

On the other hand, on a per ha basis, mineral $\mathrm{N}$ production rate was in the range of 1.21 to $2.80 \mathrm{~kg} \cdot \mathrm{N} \cdot \mathrm{ha}^{-1}$ $\cdot \mathrm{d}^{-1}$ (Table 3) after accounting for thickness and soil bulk density of the arable layer (Table 1). Compared to sandy soils (MS and AS), clayey soils (UB, RO and PV), mucky clayey soils (LP and VEp) and organic soils $(\mathrm{CH}$, VEs and VEd) showed substantial $\mathrm{N}$ release capacity. By comparison, Canadian meadow soils released $0.5-1.3$ $\mathrm{kg} \cdot \mathrm{N} \cdot \mathrm{ha}^{-1} \cdot \mathrm{d}^{-1}$ during 56 weeks of incubation at $25^{\circ} \mathrm{C}$ [6] and Canadian organic soils released $0.1-2.4 \mathrm{~kg} \cdot \mathrm{N} \cdot \mathrm{ha}^{-1}$ $\cdot \mathrm{d}^{-1}$ during 34 weeks of incubation at $25^{\circ} \mathrm{C}$ [7].

\subsection{Degree of Phosphate Saturation}

As expected, the relationship between $\mathrm{P}_{\mathrm{w}}$ and the $(\mathrm{P} /[\mathrm{Al}$ $+\gamma \mathrm{Fe}])_{\mathrm{M}-\mathrm{III}}$ percentage (Equation (3)) in mineral soils was texture-dependent [9] (Figure 2(a)). Indeed, the sandy soils required more $\mathrm{P}$ saturation to release the same amount of $\mathrm{P}$ as mucky clayey and clayey soils. Using $\gamma=$ 1 for clayey soils and $\gamma=3$ for mucky clayey soils, the distribution of points was similar. The $\gamma$ factor of 3 inflating extracted Fe was closed to $\gamma=5$ for the associated organic soils [10]. Obviously, the effect of organic matter 


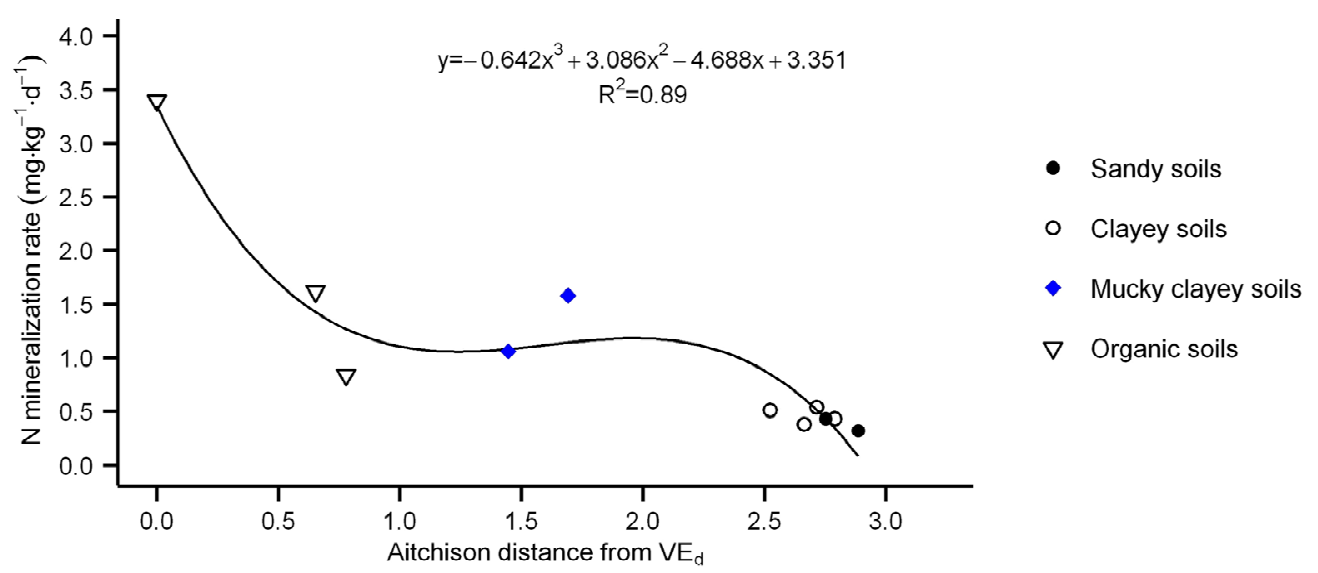

Figure 1. Aitchison distance of $\mathbf{N}$ mineralization rates in 10 soil series and variants from deep Verchères (VEd) minerotrophic (fen) peat.
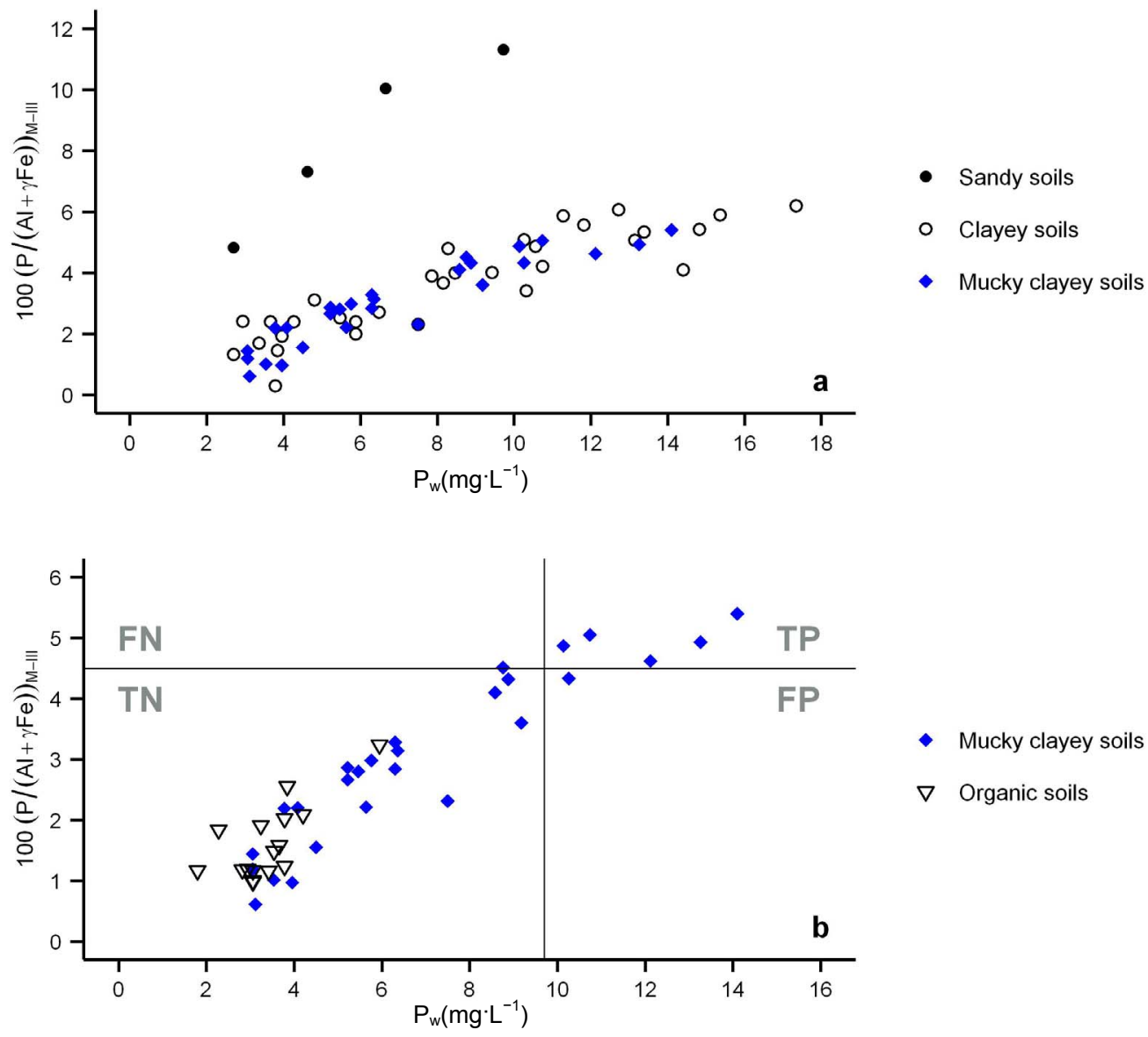

Figure 2. Cate-Nelson partitioning of the relationship between degree of $P$ saturation using the Mehlich-III method (DPS ${ }_{\mathrm{M}-\mathrm{III}}$ ) (Equation (3)) and water extractable $P\left(P_{w}\right)$ [18] using $\gamma=1$ for mineral soils, $\gamma=3$ for mucky mineral soils and $\gamma=5$ for organic soils. Mucky mineral soils behave like clayey mineral soils (a) and organic soils (b). Critical DPS mineral soils for environmental risk from subsurface drainage is $4.5 \%$. TP = true positive (well classified problem soil); $\mathrm{TN}=$ true negative (well classified healthy soil); FP = false positive (misclassified problem soil: type I error); FN = false negative (misclassified healthy soil: type II error).

content on the relationship in Figure 2(a) was greater compared to soil texture.

Organic soils $(\gamma=5)$ were all below the critical
DPS $_{\mathrm{M}-\mathrm{III}}$ value of 5\% (Figure 2(b)) proposed by [10] to minimize water pollution through subsurface drainage. Using $\gamma=3$ for mucky clayey soils, the Cate-Nelson par- 
titioning procedure correctly classified the points in the diagram at about $\mathrm{P}_{\mathrm{w}}=9.7 \mathrm{mg} \cdot \mathrm{L}^{-1}$ on the $\mathrm{x}$ axis and $4.5 \%$ on the y axis. There was just one false positive observation. Indeed, mucky clayey soils accumulated organic matter and Fe under conditions of poor drainage similar to those prevailing during the genesis of the associated organic soils [10].

\section{Conclusion}

In this paper, we showed that mucky clayey soils have the potential to release mineral nitrogen in amounts similar to organic soils. On the other hand, it appeared that the degree of $\mathrm{P}$ saturation of mucky clayey soils could be modeled using the DPS $_{\mathrm{M}-\text {-II }}$ formulation (Equation (3)) with $\gamma=3$, intermediate between $\gamma=1$ for mineral soils and $\gamma=5$ for organic soils. A critical value of $4.5 \%$ could minimize $\mathrm{P}$ loss through subsurface drainage in mucky clayey soils. Mucky clayey soils could thus be managed similarly to organic soils for $\mathrm{N}$ and using DPS $_{\text {M-III }}$ with $\gamma=3$ for P.

\section{Acknowledgements}

We thank the Québec Research and Development Institute for the Agri-Environment, the Natural Sciences and Engineering Research Council of Canada (NSERCCRDPJ 385199-09), Cultures Dolbec Inc., Groupe Gosselin FG, Agriparmentier Inc., Pro-champs Inc., and Ferme Daniel Bolduc Inc. for financial support.

\section{REFERENCES}

[1] Soil Classification Working Group, "The Canadian System of Soil Classification," 3rd Edition, Agriculture and Agri-Food Canada, 1998.

[2] Expert Committee on Soil Survey, "The Canada Soil Information System (CanSIS): Manual for Describing Soils in the Field," Agriculture Canada, Contribution No. 8252, 1983.

[3] A. Martin and M. C. Nolin, "Étude Pédologique du Comté de Chambly (Québec)," Agriculture Canada, Sainte-Foy, Contribution No. 89-26, 1991.

[4] J. W. Doran and T. B Parkin, "Defining and Assessing Soil Quality," In: J. W. Doran, D. C. Coleman, D. F Bezdicek and B. A. Stewart, Eds., Defining Soil Quality for a Sustainable Environment, Special Publication Number 35, ASA, Madison, 1994, pp. 3-21.

[5] D. L. Karlen, S. S. Andrews and J. W. Doran, "Soil Quality: Current Concepts and Applications," Advances in Agronomy, Vol. 74, 2001, pp. 1-40. doi:10.1016/S0065-2113(01)74029-1

[6] M. Sbih, A. N'dayegamiye and A. Karam, "Evaluation of Carbon and Nitrogen Mineralization Rates in Meadow Soils from Dairy Farms under Transit to Biological Cropping Systems," Canadian Journal of Soil Science, Vol. 83, No. 1, 2003, pp. 25-33. doi:10.4141/S02-006
[7] F. Duguet, L. E. Parent and A. N'dayegamiye, "Compositional Indices of Net Nitrification in Cultivated Organics Soils," Soil Science, Vol. 171, No. 11, 2006, pp. 886-901. doi:10.1097/01.ss.0000235233.47804.e6

[8] F. J. Stevenson, "Cycles of Soils. C, N, P, S, Micronutrients," John Wiley and Sons, New York, 1986.

[9] A. Pellerin, L. E. Parent, J. Fortin, C. Tremblay, L. Khiari and M. Giroux, "Environmental Mehlich-III Soil Phosphorus Saturation Indices for Quebec Acid to Near Neutral Mineral Soils Varying in Texture and Genesis," Canadian Journal of Soil Science, Vol. 86, No. 4, 2006, pp. 711-723. doi: $10.4141 / \mathrm{S} 05-070$

[10] J. Guérin, L. E. Parent and R. Abdelhafid, "Agri-Environmental Thresholds using Mehlich III Soil Phosphorus Saturation Index for Vegetables in Histosols," Journal of Environmental Quality, Vol. 36, No. 4, 2007, pp. 975-982. doi:10.2134/jeq2006.0424

[11] A. Breeuwsma and S. Silva, "Phosphorus Fertilization and Environment Effects in the Netherlands and the Po Region (Italy)," Winand Staring Centre for Integrated Land, Soil, and Water Research, Wageningen, 1992.

[12] L. Khiari, L. E. Parent, A. Pellerin, A. R. A. Alimi, C. Tremblay, R. R. Simard and J. Fortin, "An Agri-Environmental Phosphorus Saturation Index for Acid CoarseTextured Soils," Journal of Environmental Quality, Vol. 29, No. 6, 2000, pp. 2052-2052. doi:10.2134/jeq2000.00472425002900050024x

[13] J. T. Sims, R. O. Maguire, A. B. Leytem, K. L.Gartley and M. C. Pautler, "Evaluation of Mehlich-3 as an AgriEnvironmental Soil Phosphorus Test for the Mid-Atlantic United States of America," Soil Science Society of America Journal, Vol. 66, No. 6, 2002, pp. 2016-2032. doi:10.2136/sssaj2002.2016

[14] A. Pellerin, L. E. Parent, C. Tremblay, J. Fortin, G. Tremblay, C. P. Landry and L. Khiari, "Agri-Environmental Models Using Mehlich-III Soil Phosphorus Saturation Index for Corn in Quebec", Canadian Journal of Soil Science, Vol. 86, No. 5, 2006, pp. 897-910. doi:10.4141/S05-071

[15] L. Lamontagne and M. C. Nolin, "Étude Pédologique du Comté de Verchères (Québec)," Agriculture Canada, Sainte-Foy, Contribution No. 87-92, 1990.

[16] A. Mehlich, "Mehlich 3 Soil Test Extractant: A Modification of Mehlich 2 Extractant," Communication in Soil Science and Plant Analysis, Vol. 15, No. 12, 1984, pp. 1409-1416. doi:10.1080/00103628409367568

[17] G. L. Ross and C. Wang, "Extractable Al, Fe, Mn and Si," In: M. R. Carter, Ed., Soil Sampling and Methods of Analysis, Lewis Publication, Boca Raton, 1993, pp. 239246.

[18] H. A. Sissingh, "Analytical Technique of the Pw Method used for the Assessment of the Phosphate Status of Arable Soils in the Netherlands," Plant and Soil, Vol. 34, No. 1, 1971, pp. 483-486. doi:10.1007/BF01372800

[19] W. B. McGill and C. T. Figueiredo, "Total Nitrogen," In: M. R. Carter, Ed., Soil Sampling and Methods of Analysis, Lewis Publication, Boca Raton, 1993, pp. 201-211.

[20] J. L. B. Culley, "Density and Compressibility," In: M. R. 
Carter, Ed., Soil Sampling and Methods of Analysis, Lewis Publication, Boca Raton, 1993, pp. 529-540.

[21] H. Sheldrick and C. Wang, "Particle Size Distribution," In: M. R. Carter, Ed., Soil Sampling and Methods of Analysis, Lewis Publication, Boca Raton, 1993, pp. 499-513.

[22] D. G. Maynard and Y. P. Kalra, "Nitrate and Exchangeable Ammonium Nitrogen," In: M. R. Carter, Ed., Soil Sampling and Methods of Analysis, Lewis Publishers, Boca Raton, 1993, pp. 25-38.

[23] L. Khiari and L. E. Parent, "Phosphorus Transformations in Acid Light-Textured Soils Treated Locally with Swine Manure," Canadian Journal of Soil Science, Vol. 85, No. 1, 2005, pp. 75-87. doi:10.4141/S03-049

[24] SAS Institute, Inc., "SAS/STAT User's Guide," Version 9.0, SAS Institute, Inc., Cary, 2002.

[25] S. E. Parent, L. E. Parent, D. E. Rozane, A. Hernandes and W. Natale, "Nutrient Balance as Paradigm of Plant and Soil Chemometrics," In: R. N. Issaka, Ed., Soil Fertility, InTech Publisher, New York, 2012, pp. 83-114. doi: $10.5772 / 53343$

[26] P. Filzmoser, K. Hron and C. Reimann, "Univariate Statistical Analysis of Environmental (Compositional) Data: Problems and Possibilities," Science of Total Environment, Vol. 407, No. 23, 2009, pp. 6100-6108. doi:10.1016/j.scitotenv.2009.08.008

[27] J. Aitchison, "The Statistical Analysis of Compositional Data". Chapman and Hall, London, 1986. doi:10.1007/978-94-009-4109-0
[28] J. J. Egozcue, V. Pawlowsky-Glahn, G. Mateu-Figueras and C. Barceló-Vidal, "Isometric Log-Ratio Transformations for Compositional Data Analysis," Mathematical Geology, Vol. 35, No. 3, 2003, pp. 279-300. doi:10.1023/A:1023818214614

[29] P, Filzmoser and K. Hron, "Robust Statistical Analysis," In: V. Pawlowsky-Glahn and A. Buccianti, Eds., Compositional Data Analysis: Theory and Applications, John Wiley and Sons, New York, 2011, pp. 57-72.

[30] J. J. Egozcue and V. Pawlowsky-Glahn, "Simplicial Geometry for Compositional Data," In: A. Buccianti, G. Mateu-Figueras and V. Pawlowsky-Glahn, Eds., Compositional Data Analysis in the Geosciences: From Theory to Practice, Geological Society, London, 2006, pp. 145159.

[31] R. R. Simard and A. N'dayegamiye, "Nitrogen Mineralization Potential of Meadow Soils," Canadian Journal of Soil Science, Vol. 73, No. 1, 1993, pp. 27-38. doi:10.4141/cjss93-003

[32] B. Scheffer, "Nitrogen Transformation in Fen Soils [In German]," Landwirtschaftliche Forschung, Vol. 33, No. 2, 1976, pp. 20-28.

[33] M. A. Tabatabai and A. A. Al-Khafaji, "Comparison of Nitrogen and Sulphur Mineralization in Soils," Soil Science Society of America Journal, Vol. 44, No. 5, 1980, pp. 1000-1006. doi:10.2136/sssaj1980.03615995004400050026x 